\title{
FAMILY SAFETY NETS AND ECONOMIC TRANSITION: A Study of Worker Households in Poland
}

\author{
Donald Cox, Emmanuel Jimenez, and Wlodek Okrasa*
}

May 1996

*Cox; Department of Economics, Boston College, Jimenez and Okrasa, The World Bank. 
The work leading to this paper was supported in part from funds provided by the National Council for Soviet and East European Research (NCSEER), which is not responsible for its contents. Support at earlier stages of this project was provided by a grant from IRIS (Institutional Reform and the Informal Sector) at the University of Maryland, and by RPO 677-96 of the World Bank's Research Committee Support Budget. We wish to thank two referees for detailed comments on a previous version of the paper. We also received useful comments from Anjini Kochar and participants in the conferences "Privatization and Socioeconomic Policy in Central and Eastern Europe," Krakow, Poland, 1993, the Western Economic Association Meetings, Vancouver, 1994 and the Northeast Universities Development Consortium Conference, Cambridge, MA 1995. Zekeriya Eser and John Jordan provided expert research assistance. The views expressed here are the authors' own and should not be attributed to the Government of Poland, NCSEER, IRIS or the World Bank.

\author{
Abstract \\ Can Eastern European families most severely impoverished during the transition to \\ capitalism rely on private family safety nets? This question is likely critical for the \\ transition's success, but little is known about family networks in Eastern Europe. We \\ analyze newly available Polish household surveys, conducted both before and after \\ Poland's economic transition, which measure private inter-household transfers. Such \\ transfers are large and widespread in Poland, and in many ways they appear to function \\ like means-tested public transfers. They flow from high to low-income households and \\ are targeted to young couples, large families and those experiencing illness. Private \\ transfer patterns also suggest that they are responsive to liquidity constraints. Our results \\ from 1987 data indicate that private transfers could fill a non-trivial portion of the income \\ gap left by unemployment. But we also find evidence from 1992 data that family \\ networks weakened somewhat after the transition.
}


Can Eastern European families who are most severely impoverished during the transition from socialism to capitalism rely on private family safety nets for support? Consider, for example, the plight of a family whose primary earner has just been laid off from a liquidated state enterprise or a family farm rendered insolvent because of the elimination of government subsidies. Do these families have more fortunate relatives or friends who can assist with cash, in-kind help, gifts or shared housing? Conversely, which are the households that cannot rely on such support?

These questions are critical for evaluating the likelihood of successful economic transition in the Eastern bloc. On the one hand, an effective social safety net must be preserved--the rise in unemployment and widening of the income distribution could derail popular support for a quick transition to capitalism (see, for example, Kornai (1990) and Lipton and Sachs (1990)). On the other hand, governments are facing fiscal constraints which render the previous regime's universal public transfer system unsustainable.

One answer is to target public transfers to the truly needy more effectively. In the words of Calvo and Frankel (1991), when "choosing among alternative safety nets, one should be aware that there is no way to protect all segments of society" (p. 42)'. But reforming institutions to accomplish more effective targeting is difficult and takes time. Are there other options? Fortunately, public transfers are not the only means of shuffling resources from one group to another. Family networks can also achieve substantial income redistribution, privately and with no apparent coercion. ${ }^{2}$ Information about the size and flows of these private transfers would be extremely useful in determining the public funds needed to round out an adequate safety net. Private transfer information is also useful for identifying households who lack private safety nets. Targeting these families can be critical since the public sector may be their only source of insurance.

Despite the potential significance of family networks during Eastern Europe's transition, we currently know little about how they might function. In fact, we know little about even the basic facts, such as the incidence and magnitude of private transfers. 
Researchers are just beginning to explore household survey micro-data containing information about private transfers for Eastern European countries.

Part of the reason for this vacuum in policy discussions concerns availability of data. The principal objective of this paper is to fill this gap by analyzing the Household Budget Survey (HBS) for Poland. Prior information suggests that private transfers are likely to figure prominently in the Polish system of safety nets and poverty alleviation. First, existing studies, conducted by both ourselves and others, indicate that private transfers are often large and responsive to economic and demographic variables. ${ }^{3}$ For example, private transfers flow from rich to poor, just as in public tax-and-transfer systems. And increases in recipient pre-transfer income often prompt reductions in private transfers, mirroring what happens in the public sector with means-tested social insurance programs. Further, private transfers are usually targeted to vulnerable groups such as the young, the elderly, female-headed households, and those stricken by illness, unemployment or those facing income instability.

Another reason to believe that private safety nets are especially important in Poland has to do with the country's turbulent history. War, occupation and partitions are likely to have raised the value of family ties as coping mechanisms (Worach-Kardas [1983]). And there is emerging evidence that the formation of habits and traditions are important elements in family interaction, so that a history of hardship may have strengthened the cultural norms that facilitate private transfers. Poland's homogeneity of religious beliefs probably encouraged close family networks as well.

Indeed, the limited available evidence concerning private transfer and intergenerational relations in Poland points to strong ties between generations. For example, two-thirds of all elderly persons in Poland live with their children, which attests to the importance of private transfers in the form of shared living arrangements. And for all forms of care (e.g., caring for the sick, child care, help with errands and personal 
business) private familial sources are an order of magnitude more prevalent than professional sources (Worach-Kardas [1983]).

The need to understand the social and economic factors shaping private transfers-with special attention to their relationship to other forms of assistance--is justified by the increasing role of the private safety net for coping with economic hardship during the period of transition. A recent opinion survey (Rose [1992]) indicates that fully one-quarter of Polish households regard help from relatives and friends as important for their standard of living. ${ }^{4}$ According to a sociological survey conducted by GUS in January 1993, 28 percent received support from other households: in-kind (19 percent); cash (10 percent); service/help (7 percent); other forms (e.g., "life advice," 9 percent). ${ }^{5}$ The substantial duration of this assistance also matters: three-quarters of the recipient households have received at least one of these forms of assistance over a period of a year and a half. A similar proportion of households reported a significant impact on their well being from cash, non-cash or in-kind help from non-household family members. The major needs experienced by recipients--equivalently, the reasons that motivated donors--are associated with recipients' inability to cope with housing problems (21 percent could not afford to pay rent), lack of a job or job uncertainty (18 percent), and food needs (18 percent). Further, the safety net provided by other institutions is far from comprehensive. According to the same study, an estimated one-third of households in Poland requiring financial support, and a fifth of households needing in-kind help, did not receive help from the state, church or charitable organizations. This finding highlights the importance of family networks for economic reform.

Further, Poland's chronic shortages prior to economic transition--felt most dramatically during the period of martial law (1981-84)--may have spurred the development of informal trading networks, which in turn strengthen the bonds needed to facilitate inter-household risk-sharing. Shortages likely encourage inter-household trade. If one household cannot obtain soap and another is short of meat, the two might be able to 
improve their lot by trading. Trading experience could help forge the bonds of altruism and trust necessary for households to engage in risk-sharing behavior by making financial transfers.

In the next section we discuss the data for financial and in-kind private transfers. Then we describe the incidence and size of transfers and the characteristics of givers and recipients, from which we will infer whether private transfers tend to perform some of the functions of public transfers. This will be followed by a section that develops an empirical framework to address the critical policy question: to what extent do private transfers affect the incidence and effectiveness of publicly-funded safety nets?

\section{DATA SOURCES}

The data used in the analysis come from the nationwide Household Budget Survey (HBS), conducted annually by Poland's Central Statistical Office (GUS) since 1957. Different households were surveyed each quarter using a diary, i.e., a budget notebook typically completed by a female homemaker, as a collection instrument. Two-thirds of the households were re-surveyed in the corresponding quarter over the period of four years. The remaining third enter the study for just one quarter and are replaced in the following year.

The HBS provides, for various population groups, information on living conditions, measured by indicators such as income and expenditures, food consumption, durables, housing conditions and demographic conditions of households. ${ }^{6}$ In this study, we use the 1987 and 1992 rounds of the HBS. In 1987 HBS covered over 29,000 households (comprising about 90,000 persons). The households were stratified by source of income into four major socio-economic groups (the figures represent numbers of households included in GUS's calculations (GUS [1988]): 
$\underline{\text { Socio-economic Groups }}$

Employee households whose major source of income comes

from work in the socialized sector

Peasant/farmer households

whose major source of livelihood

is work on own agricultural holding

Farmer/worker households with income from both employment in socialized sector and own-account work on private agricultural holding

Pensioner households whose major source of income is old-age retirements or disability pensions or similar entitlements

Total
Number
Percentage

46.9

100.0

In 1992, the HBS was continued on a smaller sample that had entered the survey in 1990. As in 1987, it was a nationwide representative survey but only covered about 11,000 households.

The advantages and limitations of the HBS for measuring the economic status of households, and for monitoring the impact of economic reform on the population, are discussed in a comparative perspective (with the Hungarian Income Survey and the Czechoslovak Social Stratification Survey) in Garner, Okrasa, Smeeding and Torrey (1991). ${ }^{8}$ The primary strength of the HBS is that it is designed to provide the most comprehensive and timely picture of a household's material status. Nevertheless, its pre1992 versions (such as the 1987 HBS, used in this study) do have some drawbacks, the most important of which relate to coverage and to the non-response rate.

The sample covers the non-institutional population of households whose heads belong to one of the above socio-economic groups. Excluded are households headed by someone employed in the private sector (5.6 percent of employees in 1986); persons 
employed in the defense and security ministries (3.1 percent before 1989); and nomenclatura (less than 1 percent). ${ }^{9}$ Altogether, 10.5 to 11.5 percent of the population were not covered by the HBS in 1987. There is also no information about income from outside the legal/official economy. These activities were not as significant in 1987 as they were in later years. Rose's (1992) recent surveys indicate that, nowadays, every third household in engaged in some form of "uncivil economy."10

The non-response rate is rather high, and, according to experimental studies is caused by long ( 3 months per year) and detailed (diary) data collection. ${ }^{11}$ In 1987, for example, 31.0 percent of first-time households selected refused to participate and 25 percent participating in the previous year refused to re-enter the study. For 1992, the respective figures are 30.9 percent and 27 percent. ${ }^{12}$ Refusals are replaced by households closest in size and per capita income, which maintains proportions among important categories. On the other hand, refusals are non-random and the reliability of the procedure for replacing households depends on the care taken by the interviewer.

Private transfers received and given are constructed from detailed questions about income and expenditures. Cash receipts are reported directly in the income section of the questionnaire that summarizes, for the entire (quarterly) period of the study, information registered in the household's "budget-notebook," or diary. Non-monetary receipts are reported in the expenditure section of the same questionnaire as "commodities or services obtained free of charge." The quantity and value of each item is specified--the latter is estimated by both the interviewer and household, at current market prices. Thus, the category "gifts received" encompasses money, goods and services. Receipts also include bequests, dowry payments, and the value of goods received from persons living abroad. In addition, support from private non-familial sources such as charity income is included in private transfer receipts. Total transfers given equal money and the value of goods given to persons outside the household, including relatives separated from the family for at least three months (e.g., a dormitory resident). 
Because of the inclusion of transfers from abroad, bequests and charity income in receipts but not gifts, measures of transfers received and transfers given are not symmetric. Transfers given include both money and the value of goods given to persons not belonging in the household, including relatives living separately from the family for at least three months (e.g., a student living in a dormitory).

\section{EMPIRICAL WORK}

We now turn to a description of private transfer magnitudes and patterns and results from a policy simulation. Before proceeding to the details of the empirical work, we summarize our main findings. The results indicate that private transfers are an important component of income and expenditures in Poland. Among all households, gross receipts of private transfers account for 4 percent of total income in 1987. Among households who were net recipients (i.e., inflows of private transfers exceeded outflows) net receipts comprise 9 percent of their income. Nearly two-thirds of the households in our sample are involved in inter-household private transfers, either as donors, recipients, or both.

The empirical work that we describe below indicates that private transfers are responsive to the economic and demographic status of households. They flow from high to low-income households, and tend to go to the well-educated and households headed by a young couple. Transfers are also targeted to large families and those experiencing recent illness or injury. Transfers follow a pronounced age pattern, which suggests that they might be given in response to possible liquidity constraints faced by households.

To gain some understanding of the potential role of private safety nets during Poland's economic transition (which began January 1, 1990), we used our multivariate analysis to simulate the impact of earnings loss on private transfers. We predicted the boost in private transfers resulting from setting the head's earnings to zero. Using the 1987 data, we found that, in the face of these lost earnings, predicted receipts would more than double. This boost would fill 11 percent of the income void left by lost earnings of the 
household head. For single-earner households, the corresponding figure is larger--22 percent.

But there are several reasons to think that the post-transition impact could differ from that predicted from the 1987 results. On the other hand, the actual onset of unemployment could galvanize households and increase transfer activity. On the other hand, the specter of unemployment could weaken private networks if households become increasingly concerned with their own problems. And changes in public transfer income could have affected private transfers as well.

The HBS data set for 1992 helps to shed light on these issues. Though transfer incidence in 1992 was the same as in 1987, amounts received (adjusted for inflation) declined significantly. For example, the 1992 value of net transfer receipts, among recipients, was only two-thirds of what it was in 1987. And the replication of the privatetransfer impact of earnings loss using the 1992 data shows a much smaller response. Private transfer networks appear to have weakened after the transition.

\section{A. The Scope and Magnitude of Private Transfers among Worker Households}

Because of the income measurement issues discussed above, we focus solely on households whose primary earner works in a non-farm, state owned enterprise. We begin with an analysis of behavior prior to the transition by using the 1987 data. The income variables require some interpretation. One way to do this is to specify major income sources and their components, as in Diagram 1 below. Wages and salaries are considered the most reliable income data because figures are obtained from employers. Non-wage income tends to be under-estimated, especially the catch-all category, "other income." We focus on non-farm, non-pensioner households because income measurement is more straightforward for them. 
How widespread are private transfers? How large? In this section we address these questions. We find that, among the sample of worker households that we use, private transfers are extensive and significant.

One way to gauge the extent of transfers is to look at total gross transfers received and given. Nearly half of the sample received private transfers, and over a quarter gave them. ${ }^{13}$ Almost 15 percent did both, and less than 40 percent did neither. So over 60 percent of the sample participated in private transfer networks. The exact figures are presented below:

\begin{tabular}{lll}
\hline & Number & $\begin{array}{l}\text { Percentage of Sample } \\
(\mathrm{N}=12,896)\end{array}$ \\
\hline Households Giving & 3,689 & 28.6 \\
Households Receiving & 6,312 & 49.0 \\
Households Both Giving and Receiving & 1,872 & 14.5 \\
Households Neither Giving nor Receiving & 4,767 & 37.0 \\
& & \\
\hline
\end{tabular}

Since some households both gave and received, we characterize households as net donors, or net recipients, according to whether outflows of private transfers exceed or fall short of inflows. Forty-four percent of the households were net recipients and about 19 percent were net givers. We designate those whose net transfer is zero as "others." ${ }^{14}$ The exact figures for net transfers are presented below:

\begin{tabular}{lcl}
\hline & Number & $\begin{array}{l}\text { Percentage of Sample } \\
(\mathrm{N}=12,896)\end{array}$ \\
\hline Net Transfer Donors & 2,410 & 18.7 \\
Net Transfer Recipients & 5,710 & 44.3 \\
Net Transfer Equals Zero ('Others') & 4,776 & 37.0 \\
& & \\
\hline
\end{tabular}

How do net donors differ from net recipients? In table 1 we list a variety of household characteristics according to transfer status. Before contrasting these subgroups however, focus on the first column of the table, which lists the characteristics for the whole sample of non-farm employed households. Gross private transfers received comprise 4.2 percent of income from all sources (including private transfers). Among net transfer 
recipients, net transfers account for 9 percent of total household income. Net gifts among givers amount to 3 percent of their total household income. To put the Polish figures in perspective, the volume of comparable transfers in the United States, as a fraction of income, is about the same as that of Poland. ${ }^{15}$

\section{TABLE 1 ABOUT HERE}

Private transfers appear to flow from high- to low-income households. The preprivate-transfer income is lowest for net recipients and highest for net givers (table 1). Recipients have lower average social-transfer income than givers.

Those involved with private transfers are better educated than those who are not. Over 12 percent of net recipients and 13 percent of net givers attended a university, for example, compared to less than 10 percent of "others" (table 1). Recipients are younger, and givers older, than the sample average. Over 19 percent of recipient households were headed by someone under 30, compared to 10 percent of giver households. Further, the elderly (those aged 60 and over) are under-represented among recipients and overrepresented among givers. (Though, in this sample of employees, they are a small minority overall.) Similarly, there are relatively fewer pensioners among recipients compared to givers. So it appears that transfers flow from old to young among these nonfarm, employed households. We stress, however, that our results pertain to the sample of households headed by those employed in the state sector, rather than the overall household population. Recipients had slightly more frequent illness or injury requiring hospitalization during the 3-month period of the survey, compared to the whole sample. But households with invalids are under-represented among recipients. ${ }^{16}$

The unconditional means in table 1 provide an introductory illustration of transfer patterns. We now turn to a multivariate analysis of transfer incidence and amounts. 


\section{B. Specification of Transfer Functions}

We estimate transfer functions in two stages: first we consider the incidence of transfers (the transfer decision) and, conditional on a transfer occurring, the amount. In symbols, indexing households by $\mathrm{h}$, we express the latent variable that determines the transfer receipt as

$$
\mathrm{t}_{\mathrm{h}}=\mathrm{a}_{0}+\mathrm{a}_{1} \text { Resources }_{\mathrm{h}}+\mathrm{a}_{2} \text { Age }_{\mathrm{h}}+\mathrm{a}_{3} \text { Demographic }_{\mathrm{h}}+\mathrm{a}_{4} \text { Other }_{\mathrm{h}}+\varepsilon_{\mathrm{h}},
$$

and

$$
\begin{aligned}
& \mathrm{T}_{\mathrm{h}}>0 \text { iff } \mathrm{t}_{\mathrm{h}}>0, \\
& \mathrm{~T}_{\mathrm{h}}=0 \text { otherwise. }
\end{aligned}
$$

When the latent variable $t_{h}$ crosses the threshold 0 , transfers, $T_{h}$, become positive. Otherwise, they are zero. The four categories of household characteristics entered on the right-hand side of (1) are described in detail below. The stochastic term $\varepsilon_{\mathrm{h}}$ represents unobservable determinants of the transfer decision. The estimating equation for transfer amounts received is

$$
\mathrm{T}_{\mathrm{h}}=\mathrm{b}_{0}+\mathrm{b}_{1} \text { Resources }_{\mathrm{h}}+\mathrm{b}_{2} \text { Age }_{\mathrm{h}}+\mathrm{b}_{3} \text { Demographic }_{\mathrm{h}}+\mathrm{b}_{4} \text { Other }_{\mathrm{h}}+\mathrm{E}\left(\eta_{\mathrm{h}} \mid \mathrm{T}_{\mathrm{h}}>0\right),
$$

where $\eta_{\mathrm{h}}$ is a random error component.

\section{i. Household Resources}

Household resources are measured by three forms of income: wages and salaries, social security income and income from other social support. We also enter educational attainment of the head of the household as an indicator for household permanent income. ii. Age

We enter a quadratic in the age of the household head, as well as interacting age with income. If transfers are responsive to liquidity constraints, we would expect that timing of transfers would be important. Transfer incidence and amounts would be concentrated in life-cycle phases when current resources are low.

\section{iii. Demographic Characteristics}

We enter a vector of other household demographic characteristics: gender of the household head, marital status, and family size. Many studies indicate that transfers are 
targeted to female-headed households (for a review of the evidence, see Cox and Jimenez [1995]). Marital status has also been found to be an important determinant of transfers (Cox [1987]). And, holding household resources constant, we might expect more transfers to be targeted to larger families, since there would be more mouths to feed. We also include a dummy indicating whether there are pensioners present in the household, and one indicating whether there are elderly persons (aged 60 or over) but no pensioners. On the one hand, we might expect transfers to be targeted to the retired, though since this group is also collecting a pension, which could crowd out private transfers.

iv. Other Variables

We include two health indicators in the transfer functions. The first is a dummy indicating whether a household member was injured or sick enough to require hospitalization during the 3 month period of the survey. The second dummy indicates whether one or more persons in the household were collecting a disability pension. If households form co-insurance networks we might expect transfers to respond positively to the incidence of illness. We also enter dummy variables for whether the household has a telephone and a car. If having either of these enables a household to perform more interhousehold, in-kind services or have increased contact with relatives and friends we would expect them to be positively associated with private transfers.

\section{Table 2--Probit Results for Net Transfer Receipts}

Probit results for net transfer receipts are presented in table 2, column 1 . The dependent variable in the probit analysis takes a value of 1 if the household is a net recipient of private transfers, and a value of 0 otherwise. With the exception of a couple of findings, transfers appear to be targeted to low-income, vulnerable households such as those headed by the young, those experiencing recent illness or households with many children.

Household resources, measured by wage and salary income and social security income, are each inversely related to the probability of transfer receipt. Income measures are entered in logarithms, so that their impact is larger at low income levels. Increasing 
income from 20,000 to 30,000 zlotys per month reduces the probability of transfer receipt by about 8.4 percentage points. But the same increase in income at sample means $(43,180$ zlotys) would reduce the probability of transfer receipt by 4 percentage points. (See chart 1 for an illustration of the connection between pre-transfer income and the probability of transfer receipt.)

\section{TABLE 2 ABOUT HERE}

An increase in social security income from 0 to the sample mean reduces the probability of transfer receipt by 10 percentage points. On the other hand, increasing social support from 0 to its mean value raises the probability of private transfer receipt by 8 percentage points. These results are reconcilable once one considers what we are able to hold constant in the regression. The regression includes a measure of whether there are pensioners in the household, as well as the variable that represents the receipt of social security income. Thus, the coefficient of the latter measures the "pure" effect of receiving cash income in that form on private transfers and is not confounded with the possible effect of just having a pensioner present. It is therefore not surprising that in the regression, social security income, like cash income, tends to reduce the probability of receiving private transfers. In contrast, the coefficient of the variable that measures other social transfers may reflect both the effect of receiving cash income in that form, as well as the effect of the criterion for receiving the transfer. Other social transfers include family allowances, unemployment insurance, social assistance, maternity and child care benefits, and the like (see Diagram 1). The regression cannot hold constant for all the criteria for receiving these transfers because we do not have data for them (for example, we do not have a variable for the presence of a pregnant or new mother) or they are inherently unobservable (such as the criterion for receiving social assistance). Thus, even if, as we suspect, receiving cash in the form of social transfers crowds out the receipt of private transfers, we are unable to discern this because the criterion for receiving the social transfer 
would stimulate private transfers. These eligibility effects could explain the positive coefficient on other social transfers.

Private transfers follow a pronounced age pattern over the life-cycle, suggesting that they may be responsive to possible liquidity constraints faced by younger households, who may not yet have established their reputations in formal credit markets. At sample means, a household headed by an 18 year-old has a predicted probability of receiving a transfer of 51 percent. This probability falls continuously with age, to about 19 percent by age 73 (chart 2). Further, the coefficient of the "young couple" dummy variable indicates that such households are about 11 percentage points more likely than other households to receive a transfer.

\section{CHARTS 1 AND 2 AROUND HERE}

Households having a member who was hospitalized are more likely to receive a transfer--having illness or injury raises the probability of transfer receipt by 3.3 percentage points. Similarly, households with someone classified as an "invalid" (i.e., a person who qualifies for disability benefits) is 6.1 percentage points more likely to receive a transfer. Unlike the pattern prevailing in many other countries, private transfers do not appear to be targeted to female-headed households. Households headed by women are 1.3 percentage points less likely to receive (but the coefficient is not statistically significant). Part of the reason for the difference in patterns between Poland and, say, the Philippines or Peru, is that these latter countries are poorer and the disparity in well-being between male and female-headed households is likely to be more pronounced.

Being married reduces the probability of transfer receipt by 4.5 percentage points, but larger families are more likely to receive. All else equal a family of 7 is 1.4 percentage points more likely to receive a transfer than a family of 2 . Households with a pension beneficiary are less likely to receive transfers ( 7 percentage points).

While this evidence suggests that private transfers compensate for low incomes and other difficult situations, other findings from column 1, table 2 point to the contrary. Well- 
educated households, for example, are more likely to receive than those having just an elementary school education (high school: +4.0 percentage points, university: +8.6 percentage points). The education effect may be due to liquidity constraints. For example, in a study of United States households, Cox (1990) finds a striking difference between the effects of current versus permanent income on the probability of receiving a transfer--the former negative, the latter positive. The positive income effects of permanent income, though counterintuitive, can be explained by a model in which recipient households face borrowing constraints. Being better educated raises permanent income and hence desired consumption. With current income constant, the gap between desired consumption and current income rises, which increases the household's demand for a loan or need for a subsidy. If liquidity constraints are binding, private transfers might be an alternative to financial markets as a source of credit.

An alternative, and perhaps complementary, explanation for the relationship between transfers and educational attainment is unobserved parental generosity. Even when schooling is publicly provided, parents can enhance the human capital investment of children by nurturing the development of younger children and supporting expenses of older ones. Especially generous parents are more likely to give to children at every point in the life-cycle, so that current transfers and past schooling attainment are linked.

Having a phone or car also raises the probability of receiving (phone: +4.3 percentage points, car: +5.4 percentage points). Having a car or phone may indicate the ability of households to provide inter-household services and contact, increasing their chances of receiving a transfer. On the other hand, the causality in the regressions could go the other way, with transfers enabling the purchase of these items.

\section{Generalized Tobit--Transfer Recipients}

The generalized Tobit for transfer recipients is presented in the second column of table 2. Both private transfers and income are measured in logarithms. The sign pattern for the generalized Tobit is roughly consistent with that of the probit. ${ }^{17}$ 
Wage and salary income (i.e., earnings) is inversely related to amounts received,

though the point estimates indicate that the impact is small. At sample means, the elasticity of transfers with respect to earnings is -0.388 . The partial effect of an increase in earnings on transfer amounts, at sample means, is about -0.045 zlotys per 1 zloty increase in earnings. The impact of earnings on transfers is much larger in absolute value at lower earnings levels (chart 3).

\section{CHART 3 AROUND HERE}

Transfers fall with age, especially for poorer households, which is consistent with the liquidity constraints hypothesis, which predicts that transfers follow a distinct life-cycle pattern for those who have difficulty borrowing (chart 4). For example, with other variables at sample means, having pre-transfer income of 10,000 implies that transfer amounts fall by 1.6 percent per year. But a household with a 90,000 zloty income has a predicted age-transfer profile that is almost flat.

The two demographic indicators--marital status and the young-couple dummy-have large effects on transfer amounts. Young couples receive 33 percent more, and other married couples 28 percent less, than households headed by single people. Family size and number of children affect transfer amounts as well. Increasing the family size by one person raises transfers by 6.5 percent. An extra child under 18 boosts transfer amounts by 4.4 percent. Consistent with the probit results, social security and social support exert opposing effects on amounts, though neither elasticity is large.

\section{E. Giving Behavior}

The probit and generalized Tobit estimates for transfers given are shown in table 3. The probit estimates indicate that increasing earnings from 40,000 zlotys to 70,000 zlotys increases the probability of giving a transfer by 11 percentage points. Again, the logarithmic specification implies that the partial impact of earnings on the probability of giving diminishes as the level of earnings rises. 
An increase in social security income from 0 to the sample mean increases the probability of giving by 6.0 percentage points. Social support income have negligible effects on giving behavior (table 3, columns 1 and 2). The partial effect of earnings on the probability of giving declines with age, though its effect is not statistically significant.

The probability of giving also increases with education, which presumably reflects wealth effects. Those who have attended high school, "occupational" school, or university each have a higher probability of giving than the reference category, those with an elementary school education or less. For example, all else equal, attending university instead of just elementary school adds 5.2 percentage points to the predicted probability of giving a transfer.

\section{TABLE 3 AROUND HERE}

The probability of giving follows a pronounced age pattern. At sample means, the predicted probability of giving continually rises from 16 percent at age 18 to 37 percent at age 70. Part of the age pattern could be determined by the number of dependents living outside of the household, which would vary with age of the household head.

Demographic patterns for the probability of giving tend to mirror those for receiving. For example, young couples are 4.1 percentage points less likely to give. Family size exerts a strong negative effect on the probability of giving. With the rest of the variables at sample means, a household with two members has a predicted probability of giving of 32 percent. One with 7 members has a predicted probability of only 10 percent.

\section{F. A Simulation of the Effects of Job Loss on Transfers}

This section addresses the following question: If the household head had a reduction in earnings, how would private transfers respond? The question is important because we would like to gauge the extent and magnitude of private safety nets available for households who lose their jobs as Poland makes the transition from a socialist to capitalist economy. The stronger the private safety nets, the lesser the scope for effective redistribution through public income transfers. At the same time, extrapolating from the 
1987 cross-section could be problematic because the transfer function need not be stable throughout the transition. For this reason, we also examine post-transition transfer behavior in the next section.

We find that, on average, predicted private transfer receipts would increase by 133 percent if the household head lost his/her earnings. The boost in private transfers would fill about 11 percent of the income vacuum left by the job loss, though the effect varies greatly depending on whether there is only one earner in the household. So private transfers, while not availing households of complete insurance against job loss, could fill a substantial portion of the income gap caused by such losses.

We calculated the predicted probability of transfer receipt and transfer amount after setting the earnings of the household head equal to zero. So earnings of the first earner are subtracted from the pre-transfer income in the simulation. ${ }^{18}$

The results from the simulation are outlined below:

$\begin{array}{lccc}\text { Household Type } & \text { All } & 1 \text { Worker } & >1 \text { Worker } \\ \text { Actual net transfers } & 2,160 & 2,669.0 & 1,722.0 \\ \text { Actual proportion receiving transfers } & 0.445 & 0.497 & 0.400 \\ \begin{array}{l}\text { Head's earnings } \\ \begin{array}{l}\text { Predicted change in probability of transfer receipt after } \\ \quad \text { removing head's earnings }\end{array}\end{array} & +0.222 & +0.308 & +0.148 \\ \begin{array}{l}\text { Predicted change in transfers after } \\ \quad \text { removing head's earnings }\end{array} & 2,290,260 & 27,170 \\ \begin{array}{l}\text { Percentage of lost earnings replaced by change in } \\ \text { transfers }\end{array} & 10.9 \% & 5,552.0 & 553.1 \\ \end{array}$

Earnings replacement for single-worker households is higher in part because our specification implies that the transfer effects of earnings are greater in absolute value the lower are earnings. ${ }^{19}$ 
The boost in private transfers prompted by the earnings loss of the head of the household makes up for nearly 11 percent of lost income for the sample as a whole. For households with only one worker, this figure is 22 percent. So private transfers can replace a significant fraction of income in the event that an earner loses his or her job. The simulation shows that private safety nets were potentially important in Poland prior to the transition.

There are three final ideas to keep in mind concerning the simulation. First, it is a partial equilibrium exercise. We assume that one household experiences joblessness but the others do not. Since earnings loss is not widespread other households do not lose their capacity to give transfers. ${ }^{20}$ If a significant fraction of households lost their earnings at once, private safety nets could dry up rather than expand.

Second, the HBS does not link donors and recipients. Since donor incomes cannot be included in the regressions for private transfer receipts, coefficient estimates of the recipient income variables could be biased toward zero. Omitted variable bias renders our simulations conservative. The reason is that donor's income is likely to enter positively in the transfer regressions, and we would expect that incomes of donors and recipients are likely to be positively correlated. ${ }^{21}$ Taking into account the possibility that our results could be affected by omitted variable bias strengthens our conclusions that private transfers are a potentially important safety net in Poland.

Third, we must examine transfer behavior during the post-transition regime to get an accurate picture of the stability of the transfer functions through the transition. We turn our attention to a replication of the analyses above using the HBS data for 1992.

\section{RESULTS FROM THE 1992 SURVEY}

We replicated the 1987 results using the 1992 HBS. The replication of table 1 for the 1992 data is presented in table 4. The incidence of transfers is roughly the same as in 1987, but amounts are much smaller. This is the most striking difference between the 
1987 and 1992 results. For example, the average gross transfers received in the 1992 sample was 29 percent lower than that in 1987 (Zloty amounts are adjusted for inflation). ${ }^{22}$

One possible reason for the decline in gross transfers received is the general decline in incomes experienced between the two time periods. Average donor income net of social and private transfers declined $9 \%((46,369$ - 51,040)/51,040)in real terms over the 5 year period. However, transfers given actually held steady during this time. So, the income decline within the country is unlikely to have caused the shortfall in receipts, which could instead stem from a reduction in transfers from outside the state sector or outside Poland itself. ${ }^{23}$ Another possible explanation is the behavioral response to the rise in average pensions $(9 \%)$ and other social transfers $(12 \%)$. If private transfers are truly a substitute for public transfers then we would expect them to decline. Finally, a problem in any strict comparison between 1987 and 1992 arises due to the sampling biases in the HBS. Until 1992, the HBS contained only worker households in the state-sector. This may not have been much of an omission in 1987; but it was probably a more problematic one in 1992, because the economic reforms would have already started to lead to a greater part of the labor force shifting to the private sector.

\section{TABLES 4, 5 AND 6 AROUND HERE}

While transfer amounts declined by 1992, transfer incidence remained about the same. Indeed, the probit equation for net transfers received is remarkably stable across the two sample years (column 1, table 2 versus column 1, table 5 for 1992). A test for structural change generated a Chi-squared test statistic that is not significant at even the .25 level. Further, not a single coefficient estimate from the 1992 probit for transfer receipt was significantly different from its counterpart in the 1987 sample. The largest difference in the point estimates is associated with the variable for the presence of an "invalid," which is positively and significantly associated with receiving a transfer in 1987 but not 1992 .

The generalized Tobit results for net transfers received in 1992 are presented in the second column of table 5. Like the probit results, the generalized Tobits are stable across 
the two years, in the sense that, except for the differences in constant terms for the two equations, the differences in the estimated coefficients are not jointly significant. The most striking difference between the estimates is that pre-transfer income is significantly inversely related to transfer amounts in 1987 but not in 1992. At sample means, the 1992 elasticity of transfers with respect to pre-transfer income $(-0.210)$ is about half as large as in 1987.

Because transfer receipts fell in 1992, and the responsiveness of transfers to pretransfer income weakened as well, our simulation of the impact of job loss on transfer receipts generated a much weaker impact than the simulation with the 1987 data. We found that private transfers would only fill 2.5 percent of the gap left by removing the earnings of the head (compared to 11 percent for the 1987 data). And for single-earner households, the comparable figure in 1992 is 3.6 percent (versus 22 percent in 1987).

The probit and generalized Tobit equations for transfers given in 1992 are presented in table 6. The probit results (column 1) follow the same pattern with respect to pretransfer income as the 1987 results, except that the impact of education on the probability of giving a transfer was negative in 1992, though the result is not statistically significant. As with transfers received, transfers given became less responsive to pre-transfer income in 1992. The elasticity of amounts given with respect to pre-transfer income (at sample means) was less than half as large in 1992 as in 1987 (0.70 versus 1.59).

\section{CONCLUSION}

Private transfers are responsive to the economic status of households in a way that suggests they could be an important factor in ensuring the safety net during Poland's economic transition. Our simulation with 1987 data of the response of private transfers to loss of earnings of the household head indicates that a substantial fraction of lost income could be replaced by a boost in private transfers--up to 22 percent of lost earnings for households with only one worker. 
Over the two time periods for which data were available (1987 and 1992) the transfer functions appear quite stable. The primary difference is that transfer amounts (both receipts and gifts) appear less responsive to pre-transfer income in 1992 compared to 1987. However, the private transfer amounts were much lower in 1992 than in 1987. This may indicate that, with imperfect capital markets, the ability of inter-household networks to cushion shocks is weaker, since most households were affected simultaneously by economic downturns.

Two of us have conducted related research for Russia (Cox, Eser and Jimenez [1995]) and we find many patterns similar to those found here. Using Russian household survey data for 1992 and 1993, we find that private transfers help equalize the distribution of income and prevent poverty. Notably, the worsening economic conditions in Russia in 1993 were associated with a one-third falloff in private transfer amounts, though the incidence of private transfers attenuated only slightly. Thus, the pattern for Russia tends to corroborate the findings in this paper. Finding out why the private safety net appears to fray somewhat in the face of increased economic hardship in these countries is an important priority for future research. 
1. Calvo, Guillermo A. and Jeffrey A. Frankel (1991), "From Centrally-Planned to Market Economies: The Road From CPE to PCPE." NBER Working Paper no. 3698, Cambridge, MA.

2. Private income redistribution has been the topic of recent research for both developed countries and developing countries. See, for example, the surveys by Gale and Scholz (1994) and Cox and Jimenez (1990).

${ }^{3}$. See, for example, the studies reviewed in Cox and Jimenez (1990).

${ }^{4}$. A somewhat higher fraction of households indicate food among gifts and exchanges with other households--see Rose (1992), "Poland: Results of a Survey of Economic and Political Behavior." University of Strathclyde, Glasgow, Scotland, CSPP - Studies in Public Policy, No. 201.

5. GUS's note on "Pomoc Spoleczna w Swietle Badan GUS," April, 1993. The authors would also like to acknowledge R. Walicki's helpful note ("Pomoc Rodzinna," April, 1993), prepared at their request.

6. GUS, 1986, "Metoda i Organizacja Badan Budzetow Gospodarstw Domowych," (Method and Organization of Studies of Household Budgets), series Zeszyty Metodyczne (Methodological Papers) No. 62; Warsaw.

7. GUS, 1988, Rocznik Statystyczny, Warsaw.

${ }^{8}$. Garner, Okrasa, Smeeding, and Torrey (1991), "Household Surveys of Economic Status in Eastern Europe: An Evaluation," paper presented to the BLS/EUROSTAT Conference on Economic Statistics for Economies in Transition, Washington, DC, February 14-16, 1991.

9. Note that since heads and spouses may work in different sections, it is possible that spouses in our sample may be employed in these sectors.

${ }^{1}$ O. Rose (1992), "Monitoring Socio-economic Trends in Eastern Europe: A Survey- 
Based Approach," report to the World Bank (IECSE).

${ }^{1} 1$. Kordos, and Kubiczek (1991), "Methodological Problems in the Household Budget Surveys in Poland," paper presented to the Workshop on Diary Surveys, Stockholm.

12. See "Budzety Gospodarstw Domowych," GUS, Warsaw, 1988, 1993.

13. Recall from the discussion above that the definitions of receipts and gifts are not symmetric, and that there is a larger number of sub-categories for transfers received.

14. Nine households in the "others" category actually gave and received the exact same amount.

15. The assumptions underlying these calculations are as follows: $\$ 200$ billion total transfers in the U.S. in 1988, and 2/3 of these are assumed inter-vivos transfers. Intervivos transfers as a proportion of aggregate disposable income in U.S. (\$3,456.8 billion in 1988 dollars) are 0.667(200)/3,456.8 = 3.9 percent. Figures from Cox and Rank (1992) and the Economic Report of the President.

${ }^{1} 6$. Recall that this analysis focuses on the group of households headed by an employee. So our sample contains no households headed by pensioners or disabled people.

17. The probit equation used to generate the inverse Mills ratio terms for the generalized Tobits for receiving (Table 2) and giving (Table 3) uses a step, rather than a quadratic, function for age: age $<30$, age $\geq 60$, and 10 -year intervals in-between. These probit equations produce estimated partial derivatives similar to their counterparts in tables 2 and 3. We experimented with an alternative way to identify the generalized Tobit by adding the following terms to the probit used to generate the inverse Mill's ratio: a cubic term in age and interactions between age and marital status, family size and the female headship and young-couple dummies. This generalized Tobit produced results similar to the ones presented above, as did an OLS regression using the non-limit observations.

18. Those households for whom earnings were greater than pre-transfer income $(1.7$ percent of the sample) and those for whom earnings of the first earner are the sole source 
of support for the household were deleted from these simulations. The total deletion: 3.1 percent of the sample. The reason for deleting those who relied solely on earnings for support is that in the log specification the predictions become extreme at very low values of pre-transfer income.

19. Let the income coefficient in the log-transfers be denoted by "a." $\partial \mathrm{T} / \partial \mathrm{I}=\mathrm{a}$ T/I. The partial effect increases the smaller is I.

${ }^{20}$. In this sense the simulation is akin to a "gradualist" transition policy versus "shock therapy."

${ }^{21}$. For example, in the case in which private transfers flow from parents to children, the relevant correlation for omitted variable bias would be the one between parent and child incomes, which is likely to be positive (see, for example, Becker and Tomes (1986) for a survey of findings for a variety of Western countries).

22. The HBS sample was drastically reduced starting in 1992, which accounts for the sample size of 4,210 in 1992, down from 12,896 in 1987.

23. Agricultural incomes fell much more sharply than wage incomes after the transition. Unfortunately, our transfer data are aggregated across categories so we cannot ascertain the exact source of the reduction in transfers received. This is an issue that should be addressed further with other data sets. 


\section{REFERENCES}

Becker, Gary S. and Nigel Tomes, "Human Capital and the Rise and Fall of Families," Journal of Labor

Economics Vol. 4, S1-S39, July, 1986.

Calvo, Guillermo A. and Jeffrey A. Frankel, "From Centrally-Planned to Market Economies: The Road From

CPE to PCPE," NBER Working Paper no. 3698, Cambridge, MA, 1991.

Cox, Donald, " Motives for Private Income Transfers," Journal of Political Economy Vol. 95, 508-546, June, 1987.

, " Intergenerational Transfers and Liquidity Constraints," Quarterly Journal of Economics Vol. 105, 187-217, February, 1990.

and Mark Rank, " Inter-Vivos Transfers and Intergenerational Exchange," Review of Economics

and Statistics Vol. 74, 305-314, May, 1992.

and Emmanuel Jimenez, " Social Objectives Through Private Transfers: A Review," The World

Bank Research Observer Vol. 5, 205-218, July, 1990).

, " Private Transfers and the Effectiveness of Public Income Redistribution in

the Philippines," in Dominique van de Walle and Kimberly Nead, eds., Public Spending and the Poor:

Theory and Evidence, 321-346, Johns Hopkins University Press, Baltimore, 1995.

, Zekeriya Eser and Emmanuel Jimenez, "Family Safety Nets During Economic Transition: A Study

of Inter-household Transfers in Russia," Mimeographed, Boston College, October, 1995.

Council of Economic Advisors, Economic Report of the President, United States Government Printing Office,

Washington DC, 1996.

Gale, William G. and John Karl Scholz, "Intergenerational Transfers and the Accumulation of Wealth," Journal of Economic Perspectives, Vol. 8, 145-160, Fall, 1994.

Garner, Thesia, Wlodek Okrasa, Timothy Smeeding, and Barbara Boyle Torrey, "Household Surveys of Economic Status in Eastern Europe: An Evaluation," paper presented to the BLS/EUROSTAT Conference on Economic Statistics for Economies in Transition, Washington, DC, February 14-16, 1991. Kordos, Jan, and A. Kubiczek, "Methodological Problems in the Household Budget Surveys in Poland," paper presented to the Workshop on Diary Surveys, Stockholm, February 18-20, 1991. 
Kornai, Janos, The Road to a Free Economy, Shifting from a Socialist System: The Example of Hungary, W.W. Norton and Company, New York, 1990.

Lipton, David and Jeffrey Sachs, " Creating a Market Economy in Eastern Europe: The Case of Poland," Brookings Papers on Economic Activity, No. 1, 75-147, 1990.

Polish Central Statistical Office, "Metoda i Organizacja Badan Budzetow Gospodarstw Domowych," (Method and Organization of the Study of the Household Budget), series Zeszyty Metodyczne (Methodological Papers) No. 62, Warsaw, 1986.

Polish Central Statistical Office, Rocznik Statystyczny, Warsaw, 1988.

Polish Central Statistical Office, "Pomoc Spoleczna w Swietle Badan GUS," April, 1993.

Polish Central Statistical Office, "Budzety Gospodarstw Domowych," Warsaw, 1988, 1993.

Rose, Richard, " Poland: Results of a Survey of Economic and Political Behavior," University of Strathclyde, Glasgow, Scotland, CSPP - Studies in Public Policy, No. 201, 1992.

Rose, Richard, " Monitoring Socio-economic Trends in Eastern Europe: A Survey-Based Approach," report to the World Bank (IECSE), 1992.

Walicki, R, " Pomoc Rodzinna," Mimeographed. Polish Central Statistical Office, Warsaw. April, 1993

Worach-Kardas, Halina, " The Polish Family Tradition," The Gerontologist, Vol. 23, No. 6, 593-596, 1983. 
Table 1

Selected Characteristics of Polish Households by Private Transfer Status, 1987

[1]

$\underline{\text { All Households }}$
[2]

$\underline{\text { Net Recipients }}$
[3]

Net Donors
[4]

Others

Income Variables (zlotys per month)

Income before private transfers

Income before social and private transfers

Wage, salary and allowances

Total household income

Income from social security

Receives social security (proportion)

Income from other social transfers

Receives other social transfers (proportion)

First earner's wages

Wage and salary income of other workers
51,840

45,950

43,180

53,650

2,762

0.233

5,896

0.920

26,260

11,080
48,220

42,570

40,640

53,020

1,932

0.173

5,644

0.945

25,110

9,240
57,090

51,040

47,470

55,400

3,569

0.283

6,048

0.888

29,090

13,280
53,530

47,410

44,060

53,530

3,347

0.280

6,121

0.907

26,200

12,190

Education (proportions)

Elementary school

High school

Occupational type school

University

\section{Other Characteristics}

Age of household head (years)

Percentage of hh with head's age less than 30

Percentage of hh with head's age greater than 60

Percentage of hh with married head

Percentage of married hh who are young

Percentage of female headed hh

Percentage of hh with pensioner present

Percentage of hh with old non-pensioners

Percentage of hh with invalid present

Percentage of hh with member ill in last 3 months

Percentage of hh with a telephone

Percentage of hh with a car

Family size

Number of wage earner's in hh
0.223

0.297

0.365

0.112

39.410

0.149

0.010

0.947

0.186

0.285

0.133

0.032

0.046

0.076

0.197

0.293

3.633

1.584
0.195

0.311

0.369

0.120

37.000

0.193

0.006

0.929

0.272

0.277

0.093

0.019

0.040

0.079

0.195

0.306

3.757

1.503
0.204

0.315

0.346

0.133
0.266

0.272

0.369

0.091

\section{$\underline{\text { Transfers }}$}

Proportion receiving net transfers

Net transfer received (amount)

Proportion giving net transfers

Net transfer given (amount)

Proportion receiving gross transfers

Gross transfers received (amount)

Proportion giving gross transfers

Gross transfers given (amount)

Proportion both giving and receiving gross

transfers
0.443

2,124

0.187

315

0.490

2,259

0.286

449

0.145

12,896
1.000

4,798

0.000

0

1.000

5,006

0.222

208

0.222
42.270

0.100

0.018

0.970

0.110

0.283

0.164

0.042

0.044

0.083

0.232

0.335

3.341

1.662

0.000

0

1.000

1,683

0.246

222.3

1.000

1,905

0.246
40.860

0.122

0.012

0.956

0.121

0.295

0.165

0.044

0.055

0.067

0.181

0.258

3.633

1.642

0.000

0

0.000

0

0.002

2.898

0.002

2.898

0.002 
Table 2

Probit and Generalized Tobit -- Net Transfers Received, 1987

[1]

Probit

Variable Name
Coefficient $\underline{\text { T-Ratio }}$

$-0.6388$

$-0.0329$

0.0261

0.0030

Log income*head's age

\section{Education Variables}

High school

Occupational type school

University

\section{Other Characteristics}

Head's age

Age squared

Married household

Young couple

Female headed household

Pensioner in household

$\mathrm{HH}$ with old non-pensioners

Invalid in household

Ill last 3 months

Household has phone

Household has car

Family size

HH with children less than 18

Constant

Inverse Mill's ratio

Number of observations

Dependent variable mean

Log-likelihood

Chi-squared
0.0958

$-0.0320$

0.2092

2.7740

$-0.9830$

4.5020

0.2971

0.3648

0.1120

$-0.0547$

0.0001

$-0.1193$

0.2843

$-0.0337$

$-0.1951$

$-0.0808$

0.1610

0.0875

0.1138

0.1428

0.0074

0.1323

7.0483

$-\cdot$

12,896

0.4427

$-8109.9$

1488.5
$-1.7370$

0.4940

$-1.9970$

7.4600

$-1.1040$

$-3.4860$

$-1.0770$

2.3420

2.0130

3.5490

5.1970

0.3970

6.2480

5.8380

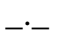

39.4123

$1,642.6795$

0.9466

0.1858

0.2850

0.1331

0.0325

0.0463

0.0756

0.1969

0.2933

3.6334

1.3362

--

$-\cdot$

R-squared
F-statistic
[2]

Generalized

Tobit

Coefficient

T-Ratio

Variable

mean

0.2041

2.9740

0.3105

0.0811

1.4910

0.3694

0.4355

3.8890

0.1203

$-0.0813$

$-1.5400$

36.9977

$-0.0002$

$-0.8820$

$1,441.0730$

$-0.3269$

$-3.3210$

0.9287

0.2848

2.6650

0.2715

$-0.0587$

$-1.1010$

0.2771

$-0.2726$

$-2.0240$

0.0932

$-0.1512$

$-0.9800$

0.0187

0.3391

2.3140

0.0401

0.0714

0.9400

0.0793

0.0859

1.2640

0.1954

0.2247

3.2860

0.3056

0.0627

1.9130

3.7571

0.0430

0.6930

1.5713

14.3150

6.7900

0.5780

0.8104

Note: Zloty denominated variables are in 1986 zlotys per month 
Table 3

Probit and Generalized Tobit -- Net Transfers Given, 1987

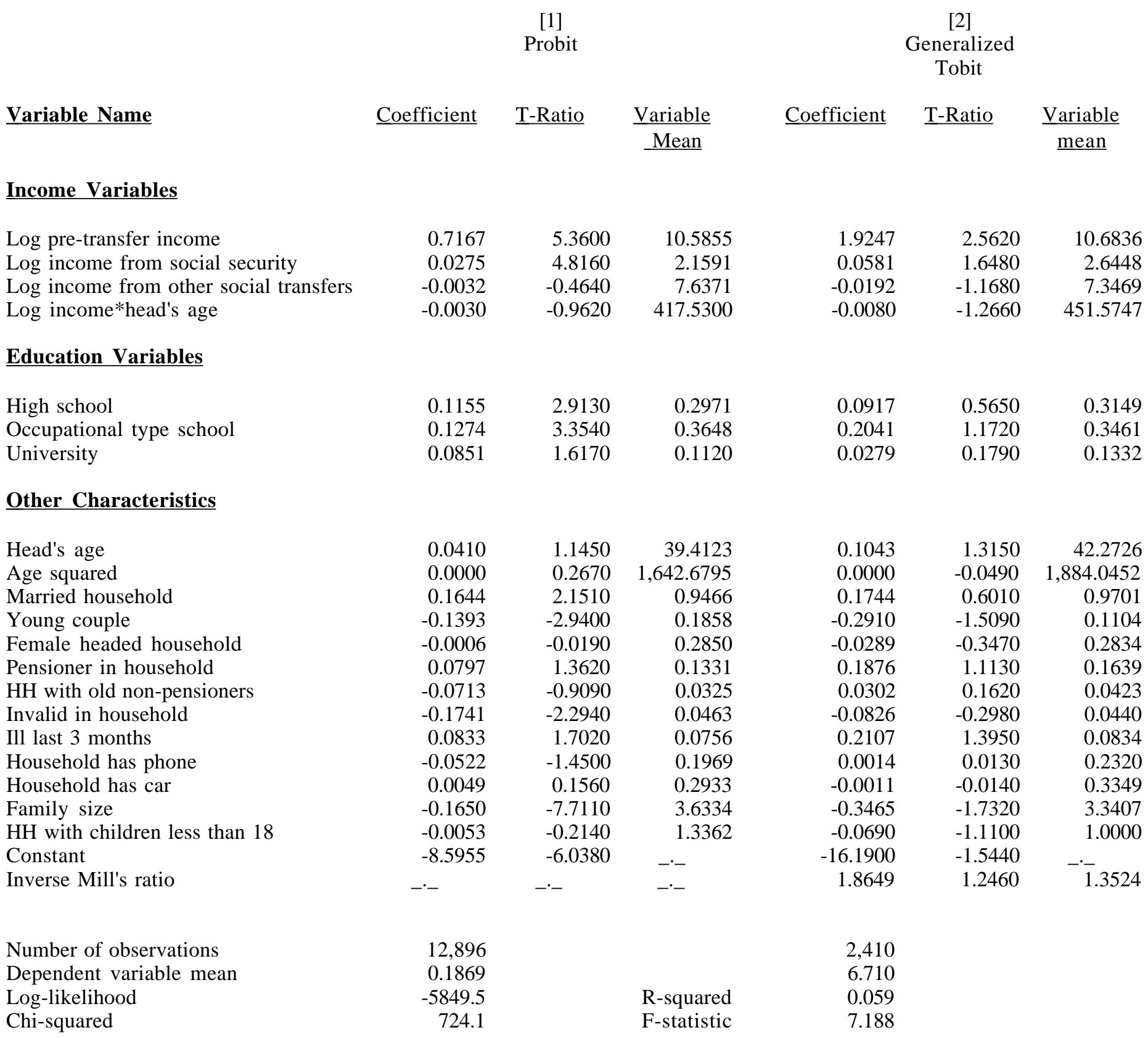

Note: Zloty denominated variables are in 1986 zlotys per month 
Table 4

Selected Characteristics of Polish Households by Private Transfer Status, 1992

$[1]$

$\underline{\text { All Households }}$
[2]

$\underline{\text { Net Recipients }}$
[3]

Net Donors
[4]

$\underline{\text { Others }}$

Income Variables (zlotys per month)

Income before private transfers

Income before social and private transfers

Wage, salary and allowances

Total household income

Income from social security

Receives social security (proportion)

Income from other social transfers

Receives other social transfers (proportion)

First earner's wages

Wage and salary income of other workers

$\begin{array}{cc}49,122 & 46,054 \\ 42,518 & 39,585 \\ 39,509 & 37,350 \\ 50,321 & 49,190 \\ 3,012 & 2,237 \\ 0.269 & 0.217 \\ 6,604 & 6,462 \\ 0.918 & 0.939 \\ 22,814 & 21,582 \\ 9,010 & 7,926\end{array}$

Education (proportions)

Elementary school

High school

Occupational type school

University

Post high school, not university

\section{Other Characteristics}

Age of household head (years)

40.300

0.141

0.337

0.362

0.137

0.023

0.126
0.347
0.366
0.138
0.025

0.117

0.008

0.949

0.135

0.395

0.137

0.016

0.040

0.066

0.309

0.412

3.584

1.405

Family size

Number of wage earner's in hh
38.550

0.135

0.004

0.934

0.189

0.400

0.097

0.008

0.032

0.069

0.297

0.418

3.703

1.361

$\begin{array}{cc}56,560 & 49,598 \\ 49,369 & 43,096 \\ 44,957 & 39,730 \\ 54,894 & 49,598 \\ 4,411 & 3,368 \\ 0.343 & 0.302 \\ 7,188 & 6,506 \\ 0.909 & 0.895 \\ 26,504 & 22,644 \\ 11,025 & 9,469\end{array}$

0.137

0.353

0.318

0.161

0.031

43.130

0.083

0.022

0.963

0.064

0.387

0.215

0.036

0.055

0.060

0.350

0.454

3.327

1.467

0.165

0.315

0.380

0.124

0.017

\section{$\underline{\text { Transfers }}$}

Proportion receiving net transfers

Net transfer received (amount)

Proportion giving net transfers

Net transfer given (amount)

Proportion receiving gross transfers

Gross transfers received (amount)

Proportion giving gross transfers

Gross transfers given (amount)

Proportion both giving and receiving gross

transfers
0.475

1,491

0.174

290

0.525

1,607

0.278

406

0.153
1.000

3,139

0.000

0

1.000

3,301

0.218

162

0.218
0.000

0

1.000

1,666

0.281

221

1.000

1888

0.281
41.260

0.109

0.007

0.961

0.099

0.392

0.153

0.018

0.044

0.065

0.306

0.384

3.551

1.432

0.000

0

0.000

0

0.002

2

0.002

2

0.002 
Table 5

Probit and Generalized Tobit -- Net Transfers Received, 1992

[1]

Probit

Variable Name
Coefficient $\quad \underline{\text { T-Ratio }}$

$-0.7058$

$-0.0229$

0.0309

0.0062
0.1479

0.0175

0.2443

2.3420

0.2860

3.0540

0.3366

University

\section{Other Characteristics}

Head's age

Age squared

Married household

Young Couple

Female headed household

Pensioner in household

$\mathrm{HH}$ with old non-pensioners

Invalid in household

Ill last 3 months

Household has phone

Household has car

Family size

HH with children less than 18

Constant

Inverse Mill's ratio

Number of observations

Dependent variable mean

Log-likelihood

Chi-squared

$$
\begin{array}{r}
-0.0570 \\
-0.0003 \\
-0.1813 \\
0.2957 \\
0.0378 \\
-0.2004 \\
-0.1432 \\
-0.0352 \\
0.0514 \\
0.0381 \\
0.1307 \\
-0.0046 \\
0.1257 \\
7.0963 \\
-- \\
\\
\\
4,210 \\
0.4751 \\
-2724.1 \\
377.5
\end{array}
$$

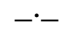

\begin{tabular}{rr}
-1.0520 & 40.2960 \\
-0.9550 & $1,700.2708$ \\
-1.7660 & 0.9487 \\
3.9700 & 0.1354 \\
0.8220 & 0.3948 \\
-2.2670 & 0.1368 \\
-0.7670 & 0.0162 \\
-0.2830 & 0.0401 \\
0.6360 & 0.0658 \\
0.7960 & 0.3093 \\
2.9500 & 0.4121 \\
-0.1470 & 3.5841 \\
3.4940 & 1.2810 \\
3.2840 & \multicolumn{2}{c}{$-\cdot$} \\
-- & - \\
\hline
\end{tabular}

10.4788

2.4707

7.8233

422.5487

0.3622

0.1368

-0.2861
-0.0209
0.0343
0.0019

$-0.8320$

$-1.2680$

1.4900

0.2320

$\underline{\text { Coefficient }}$

0.2119

0.0420

0.3614

1.7890

0.4390

2.1520

0.0017

$-0.0004$

$-0.3334$

0.3515

$-0.0059$

$-0.2645$

0.6083

0.2357

0.2452

0.1100

0.0249

0.0193

0.1528

9.4275

0.1854

2,000

7.2660

R-squared

F-statistic

0.066

6.617
10.4232

1.9741

8.0004

402.0618
0.3470

0.3655

0.1375

$\begin{array}{rr}0.0190 & 38.5460 \\ -0.9230 & 1,551.6620 \\ -2.0340 & 0.9340 \\ 2.3130 & 0.1885 \\ -0.0810 & 0.3995 \\ -1.4380 & 0.0965 \\ 1.5910 & 0.0075 \\ 1.0960 & 0.0320 \\ 2.0150 & 0.0685 \\ 1.4690 & 0.2970 \\ 0.2830 & 0.4175 \\ 0.3800 & 3.7025 \\ 1.9800 & 1.4805 \\ 2.7520 & -\cdot- \\ 0.2580 & 0.7782\end{array}$

Note: Zloty denominated variables are in 1986 zlotys per month 
Table 6

Probit and Generalized Tobit -- Net Transfers Given, 1992

[1]

Probit

Variable Name

Income Variables

Log pre-transfer income

Log income from social security

Log income from other social transfers

Log income*head's age

$\underline{\text { Coefficient }} \underline{\text { T-Ratio }} \quad \frac{\text { Variable }}{\underline{\text { Mean }}}$

0.8456

0.0100

0.0160

$-0.0059$

3.3540
1.0510
1.2790
-1.0300

10.4788

2.4707

7.8233

422.5487

0.1713

0.0452

$-0.0282$

1.1240

0.3525

$-0.0469$

$-0.6450$

Occupational type school

University

0.3622

0.1368

0.2980

$-0.1390$

0.3183

0.1612

Other Characteristics

Head's age

Age squared

Married household

Young Couple

Female headed household

Pensioner in household

$\mathrm{HH}$ with old non-pensioners

Invalid in household

Ill last 3 months

Household has phone

Household has car

Family size

HH with children less than 18

Constant

Inverse Mill's ratio

Number of observations

Dependent variable mean

Log-likelihood

Chi-squared

$$
\begin{array}{r}
0.0846 \\
-0.0001 \\
0.1385 \\
-0.2412 \\
-0.0302 \\
0.2744 \\
0.2076 \\
0.0112 \\
-0.0684 \\
-0.0716 \\
-0.0338 \\
-0.1451 \\
-0.0253 \\
-10.1740 \\
-- \\
\\
\\
4.210 \\
0.1739 \\
-1817.8 \\
254.3
\end{array}
$$

1.3100

$-0.4330$

1.0730

$-2.4150$

$-0.5560$

2.8250

1.1490

0.0840

$-0.6930$

$-1.2780$

$-0.6470$

$-3.8860$

$-0.5870$

$-3.8190$

40.2960

$1,700.2708$

0.9487

0.1354

0.3948

0.1368

0.0162

0.0401

0.0658

0.3093

0.4121

3.5841

1.2810

$-\cdot$

$\begin{array}{rrr}-0.1774 & -1.3420 & 43.1298 \\ 0.0014 & 2.2950 & 1,940.2992 \\ -0.0651 & -0.2150 & 0.9631 \\ -0.3982 & -1.3530 & 0.0642 \\ -0.0954 & -0.8330 & 0.3866 \\ 0.0720 & 0.2870 & 0.2145 \\ -0.2585 & -0.7700 & 0.0355 \\ -0.0544 & -0.2170 & 0.0546 \\ -0.0306 & -0.1470 & 0.0601 \\ -0.0505 & -0.4090 & 0.3497 \\ -0.0970 & -0.8950 & 0.4536 \\ -0.1397 & -1.1420 & 3.3265 \\ 0.0499 & 0.5470 & 0.9699 \\ 4.8040 & 0.6230 & -- \\ -0.0806 & -0.0990 & 1.3762\end{array}$

732

6.685

R-squared $\quad 0.081$

F-statistic $\quad 2.996$

Note: Zloty denominated variables are in 1986 zlotys per month 
Chart 1: Probability of Net Transfer Receipt as a Function of Head's Age, 1987

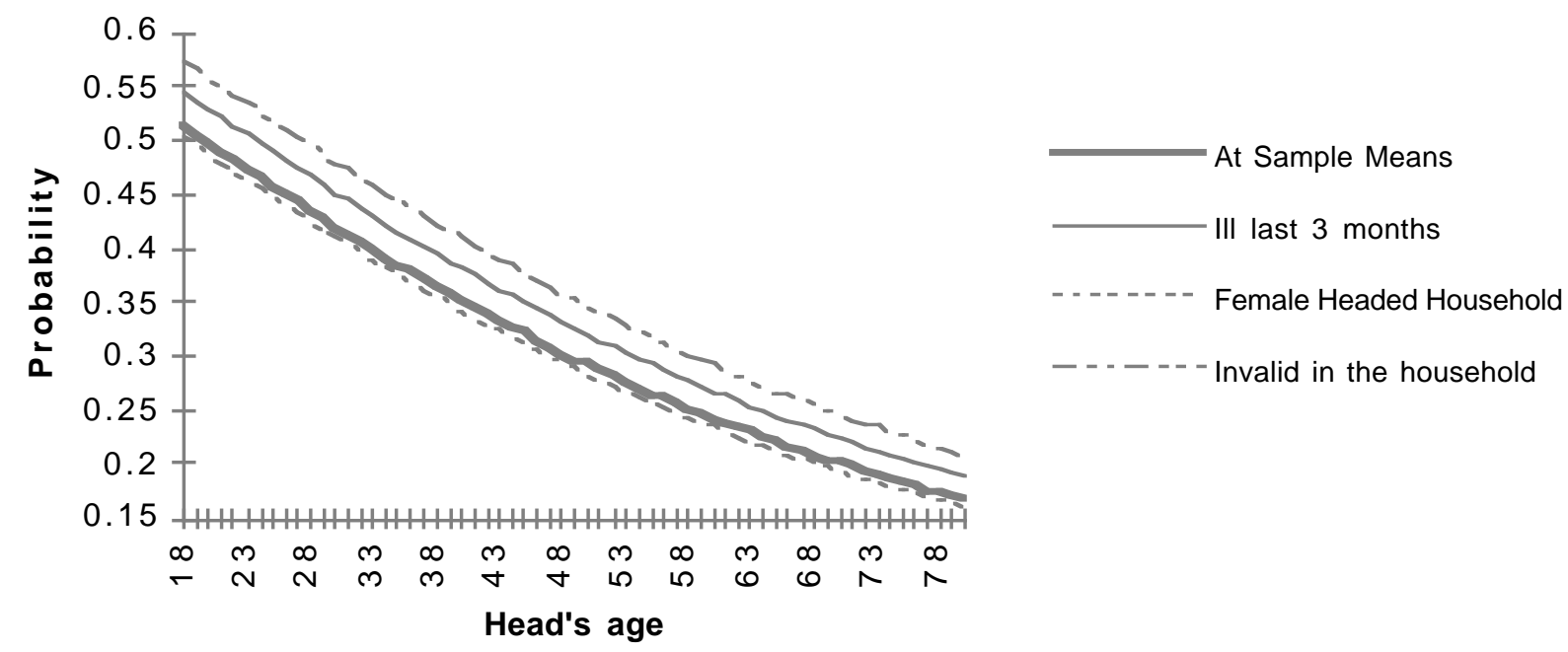

Chart 2: Probability of Net Transfer Receipt as a Function of Pre-Transfer Income, 1987

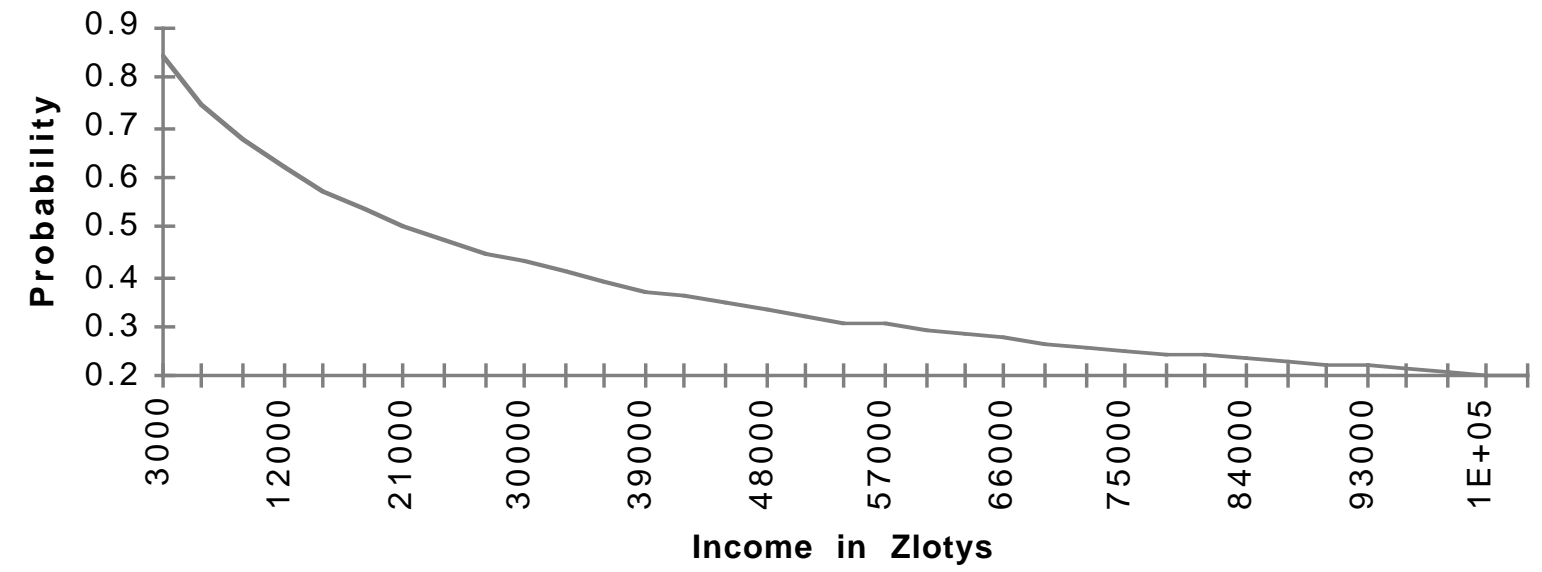

Source: Net Transfer Receipt Probit. Table 2, Column 1 
Chart 3: Net Transfers Received -- Prediction from Generalized Tobit as a

Function of Head's Age, 1987

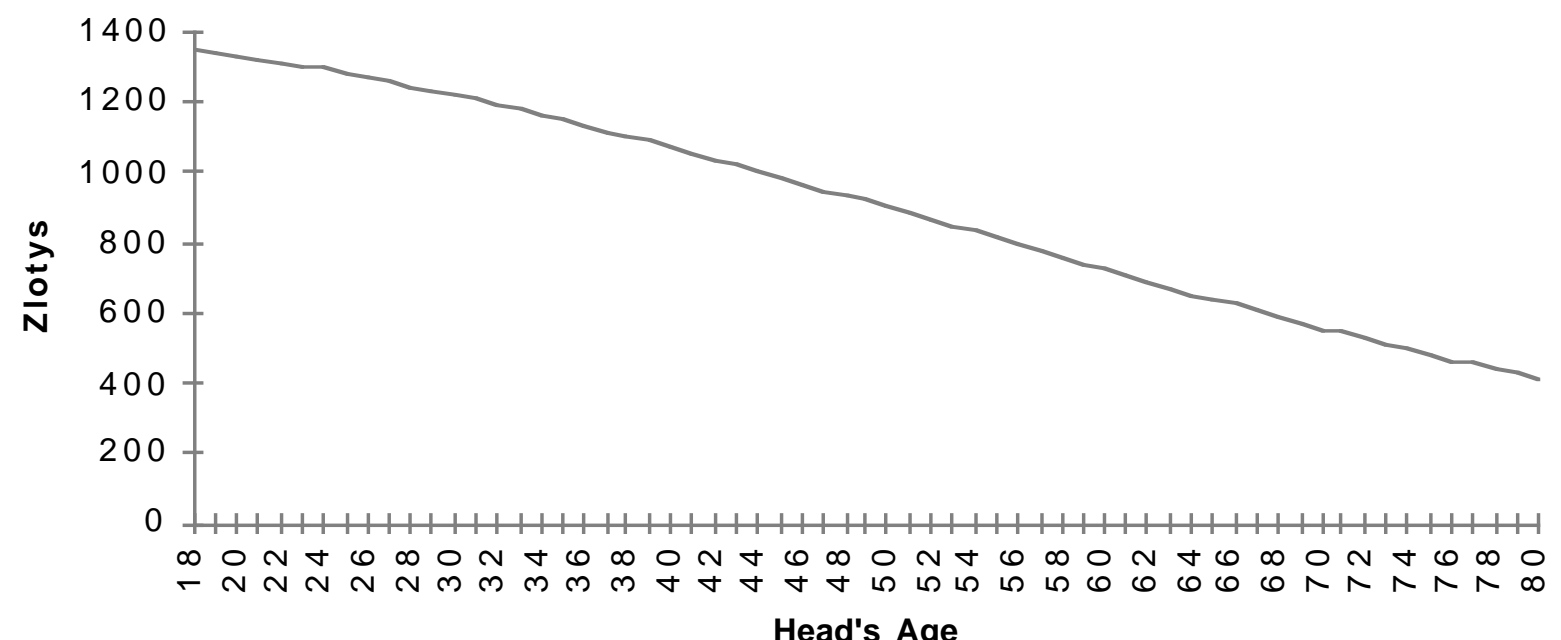

Head's Age

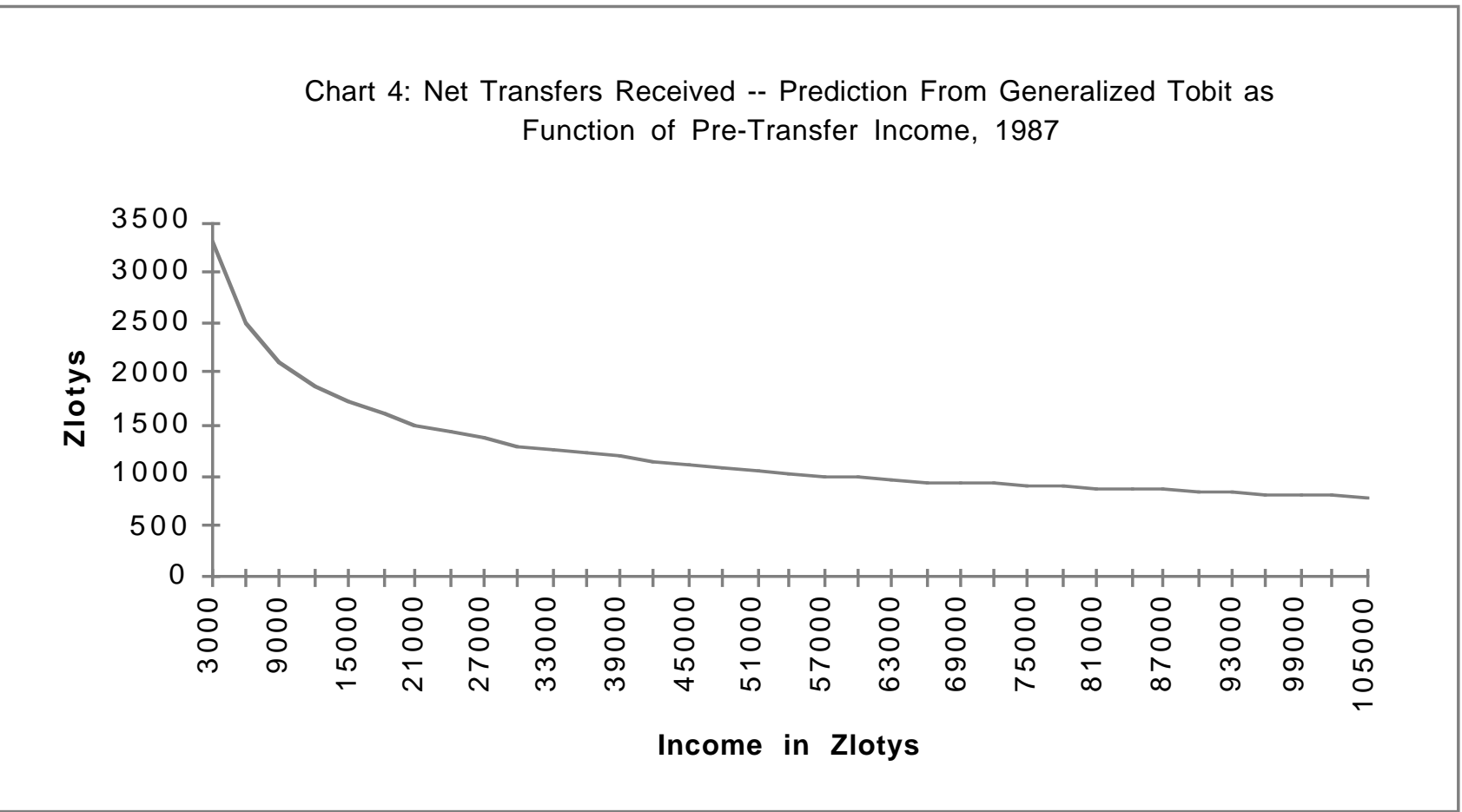

Source: Net Transfer Receipt Generalized Tobit. Table 2, Column 2 


\section{Diagram 1}

\section{Sources of Household Income in Poland}

\section{Labor Income}

(Socialized Sector) -Personal Wage Fund, including wage payment in-kind, about $1 \%$

of the fund

-Compensation for price increase

-Payment from profit/gain of corporation

financial results)

-Payment from enterprise's fund of rewards

-Payment for contracted job and honoraria, etc.

-Franchise/commissions -Other (e.g., once-paid grant for moving, relocation, etc.)

-Casual job in the private sector/Miscellaneous
Social Transfers

Social Security -old-age pensions

-family pensions -disability pensions Other Social Transfers Family Allowances -child-care allownaces -maternity allowances -other allowances, e.g.,

birth, death

Other Social Payments

(Cash)

-family compensation -stipends/scholarships -employer's grant

(Non-cash)

-stipends for canteen -holiday camps/holiday pay

-30 percent of cost of medication for pensioners -goods/allowances for the elderly/disabled

\section{Farm Self-Employment Other Sources} Income

of Income

From individual farm Income from (plot) net of farm (plot) -selling goods operating expenses, -leasing/rent including foodstuffs -indemnity and non-foodstuffs -private transfers consumed in the -games and lotteries household Other income -dissaving -loans/credits (net 